\title{
WWW 上の利用者評価を導入した建材データベース検索語の分析 ANALYZING KEYWORDS OF BUILDING MATERIAL DATABASE
BY USER EVALUATION ON THE WEB
}

\author{
木村 謙*, 渡辺仁 史** \\ Takeshi KIMURA and Hitoshi WATANABE
}

\begin{abstract}
A new method of extracting search keywords has been introduced which is based on combining the statistical analysis of user access and user evaluation by simple web polling. DbNET, an actually working database of building materials and equipment, has been chosen for the source of experiment, and with the specialist oriented aspect of this database, the analyzing of user access implies expert judgment of information value. The results shows that the simple polling system work as an effective evaluation method for extracting search keywords, and from the case study the proposed system was proved to suggest an efficient database structure.
\end{abstract}

Keywords: WWW, Access log, Information retrieval, Expert judgement, Database, Search engine WWW、アクセスログ、情報検索、エキスパートジャッジメント、データベース、検索エンジン

\section{1.はじめに}

World Wide Web (以下 WWW) での情報検索サービス注1)利用が 一般的となるにつれ、適切な検索語（キーワード）の選択の難しさ が広く認識されるようになった。この問題が特に影響を及はすの は、単語入力のみで検索を行う場合であり、その解決のために様々 な試みがなされている1注2)。

これらの試みでは、情報を提供する各コンピュータ（以下サー バー）上の情報配信の記録（以下ログ）を統計的に分析することで、 利用者が抽出した情報と情報抽出に利用した検索語の関係を明かに している。構文解析技術を応用し、検索語の辞書を作成して検索の 精度を上げる試みもある。

本研究ではWWW上で公開している建材データベースを対象とし て、ログから利用者の情報収集行動（どのように検索したか）を解 析し、さらに利用者による検索結果の評価を行っている。また、検 索語が利用される頻度をもとに、検索語の特徽を分析している。そ して、これらを統合した検索語抽出の新たな手法を示し、その応用 可能性を明らかにするものである。

\footnotetext{
* 早稲田大学理工学総合研究センター 客員講師・工修

**. 早稲田大学理工学部 教授.工博
}

\section{2. 本研究の位置づけ}

ログをもとにした情報収集行動の研究としては、グループ内の各 メンバーの WWWサーバーへのアクセスログからグループ全体の WWW 利用特性を数量化する試み2)等がある。検索語の関係性を口 グから解析した研究として、検索語のログに出現する頻度と時間間 隔とから語の関係を求めるもの3等がある。統計的手法を用いて自 動的にシソーラス構築を構築する方法4)も提案されている。このよ うに情報処理の分野で関連した研究が行われているが、対象となる 利用者、情報源は一般的で実験的なものであることが多い。

これらに対して本研究は、長期間にわたる実働システムの運用結 果をもとに展開してお.り、信頼性が高く実用的な知見を提供するも のである。また、建材商品という特定分野の情報を对象としている ため、アクセスする利用者も専門家が多い。このことから、本研究 で採用している利用者による評価では、エキスパートジャッジメン 卜的な効果が得られる。これらの結果を応用して的確な情報検索・ 情報抽出のための辞書作りも可能になると考えられる。 


\section{3. 対象データベースの概要}

\section{$3.1 \mathrm{dbNET}$}

本研究では、筆者らが1997年より開発を続けている建材・設備機 器商品のデータベース「dbNET」注4)のログを元にシソーラスの構築 を行った。本データベースについて、検索と言う視点から概要を示 すとともに、利用結果について明かにする6。

なお、ログの対象期間は 2000 年 1 月 1 日午前 0 時より 2001 年 1 月 1 日午前 0 時までの一年間である。

\section{2 データ構造}

建材データベースは約 9,300 注5)のファイルで構成されており、検 索の対象となる主要ファイル数は約 7,700である注6)。商品情報は、 各メーカー各商品種毎に一つのファイルに記載され、商品種によっ て階層的に分類されている。

\section{3 検索方法}

当データベースの情報検索の仕組みのうち、本研究で主に扱うの は「分類検索」と「外部の情報検索サービス」である。前者は階層 化された情報を階層に沿って閲覧する方法である。後者は、検索語

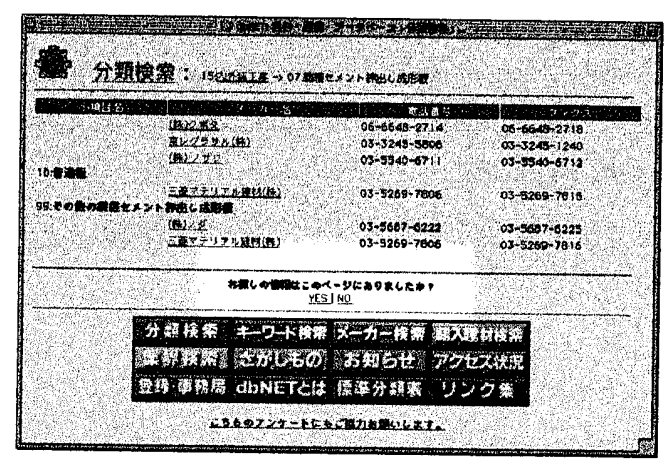

図1: 利用者評価アンケート画面

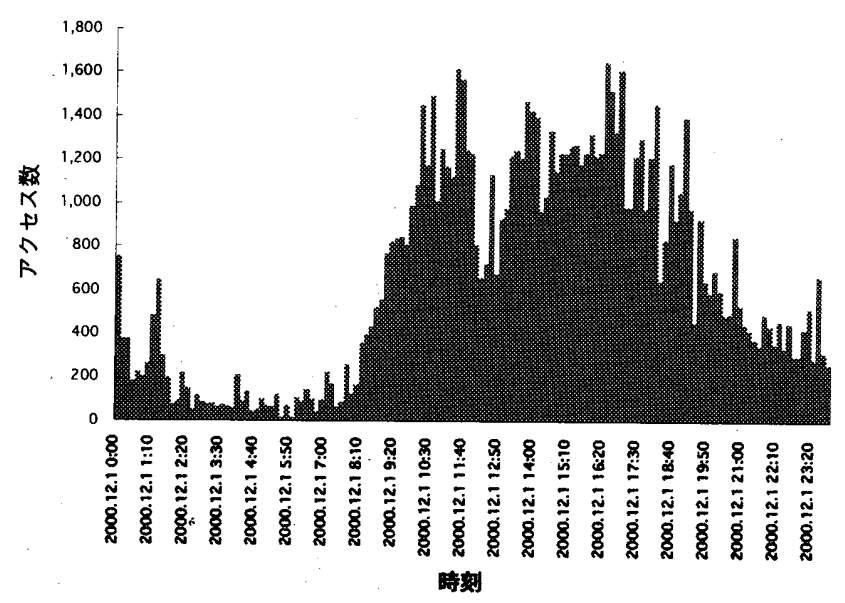

图 3：時間毎アクセス数 $(2000.12 .1)$
を入力して検索する一般的な情報検索サービスの検索結果から間接 的に本データベースを検索する方法である。

\section{4 検索結果の利用者評価}

データベース中の主要ファイルについては、利用者に対して検索 されたファイルの内容が要求と合致しているかについて簡単なアン ケート（検索結果評価アンケート）を行っている（図 1)。アンケー トの際にどのように検索して（前節二つの方法）そのファイルを選 択したかも自動的に記録している。このアンケート結果を検索結果 の利用者評価としている。

\section{5 利用者層 - 利用状況}

利用者の属性調查から利用者の大部分は専門家であることがわ かっており注》、本データベースへのアクセス、検索に際しては一定 の評価が行われていると考えられる注8)。その結果を集計することで エキスパートジャッジメントと同等の効果が期待できる。

利用者のアクセスは平日に多く(図2)、オフィスアワーに合わせ 朝 8 時頃からアクセスが増え、昼休みの時間帯に少し減り、夜 8 時 頃から減り始める（図3）。これは、典型的なビジネス目的のアクセ

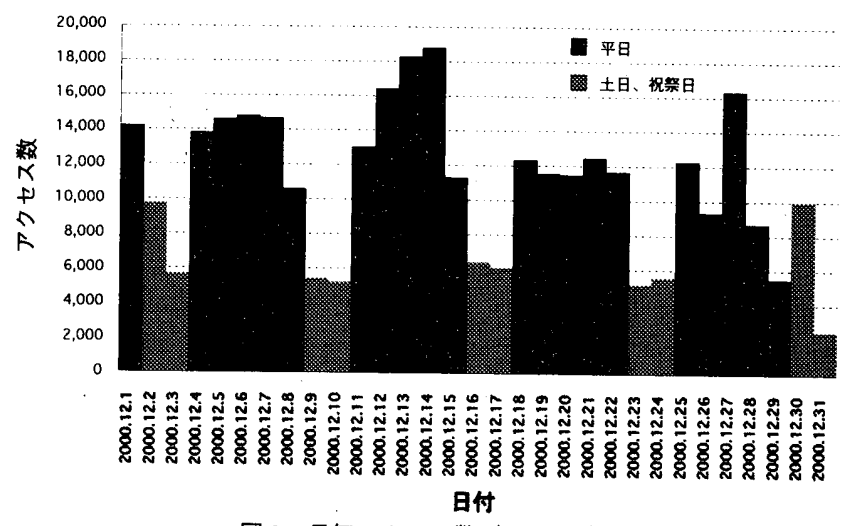

図 2：日毎アクセス数（2000.12）

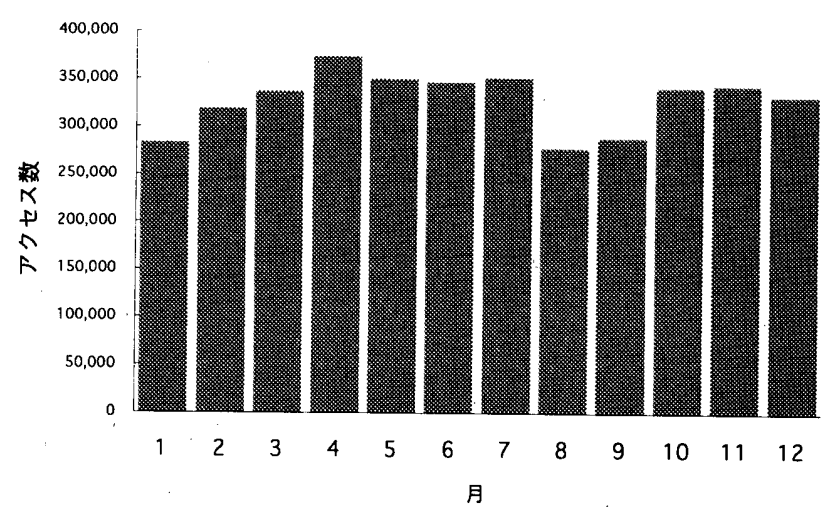

図 4：月每アクセス数（2000 年）

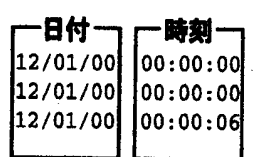

$$
\text { ht }
$$

http: / /dbnet.watanabe.arch. waseda.ac.jp/productSearch02/Default. htm1 http: //dbnet. watanabe.arch.waseda.ac.jp/productSearch02/Default.html http: //www goo. ne.jp/default . asp?MT=8BE\&AE\&BB\&E5\&B98A98B6\%C8\%288B38F48A18CB\&act. next $=1$

図 $5:$ ログの例 :productsearch01:B:2429. htm 
スパターンといえ、このことからも業務で利用している専門家の利 用が多いと判断できる。

主要ファイルへの月毎アクセス数は 30 万から 35 万前後で推移し ており（図 4)、2000年 12 月を例にとると、全体のアクセス数が約 59 万、主要ファイルへのアクセス数は約 33 万であり、調査対象の 母集団として充分なアクセスがある。

\section{4. ログからの検索言抽出}

\section{1 ログに記録されている情報}

ログにはファイルの取り出し要求毎に図5のような記録が残され る注9)。ログには referer 注10)が記録されており、この情報を元に、分 類検索におけるファイルを検索した順序や、外部の情報検索サービ ス利用において何が検索語として用いられたかを知る手がかりが得 られる。

\section{2 ログ解析}

外部の情報検索サービスを利用して検索された場合には、図 5 の 3行目のようにrefererの項目に様々な情報が付加される注11)。これを 解析することで、このファイルの要求は、どのような検索指令の結 果発生したかということがわかる注12)。

具体的には、まずはじめに、refererの項目に付加情報のあるもの を抽出する注13)。次にこの項目のデータを解析し、検索サービスの 特定を行い、検索指令を解明する。そして、検索指令のどの部分が 検索語であるかを明らかにする。

例えば、referer 項目が次のようであったときに、

http: //www. aaa.ne.jp/default. asp?WORD=8B7\&FA\&BA\&E0\&PAGE=1 サーバーのアドレス「www.aaa.ne.jp」より AAAという検索サー ビスを利用したことが分かり、検索指令のパラメーターとして、 「WORD」と「PAGE」があることがわかる。そしてAAAのサイト を解析することで「WORD」が検索語のパラメーターであることを 明らかにすることができる。ここでの検索語は「建材」である注14)。

最後に、抽出された検索語に対して文字コードや、アルファベッ トのケースなどの簡単な正規化を行い検索指令からの検索語の抽出 が完了する。

すべてのログ、検索サービスに対してこの作業を繰り返し、対象 となる検索指令を解析した結果、検索サービスからのアクセスは 918,419件で、内917,382件が解析可能であった。すべてのアクセス の内 $99.9 \%$ が解析できたことになる。今回の対象データでは、45の 検索サービスを利用したアクセスがあった注15)。

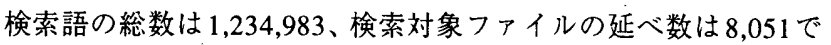
あり、ファイル数に対して充分に多くの検索語があった。

\section{3 検索語とファイル数の関係}

抽出された検索語に対して集計を行った。次に各集計項目とその 特徴を記す（表 1)。

(1)検索語毎のファイル種類

「一つの検索語がどれだけ多種のファイルを取り出したか」 この値が低い程、検索語が特定の情報抽出に用いられている と考えられる。

(2)検索語毎のファイル数

「一つの検索語がどれだけ多数のファイルを取り出したか」

この值が高い検索語は情報の抽出能力が高いと考えられる。
表 $1:$ 検索語毎集計

\begin{tabular}{|c|c|}
\hline (1) & (3) \\
\hline 90パーセンタイル & 4 \\
\hline 85パーセンタイル & 3 \\
\hline 75パーセンタイル & 2 \\
\hline 中央值 & 1 \\
\hline 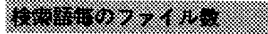 & $(3)$ \\
\hline 90パーセンタイル & 12 \\
\hline 85パーセンタイル & 7 \\
\hline 75パーセンタイル & 3 \\
\hline 中央値 & 1 \\
\hline 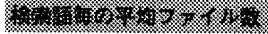 & 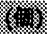 \\
\hline 90パーセンタイル & 3.2 \\
\hline 85パーセンタイル & 2.3 \\
\hline 75パーセンタイル & 1.7 \\
\hline 中央値 & 1.0 \\
\hline
\end{tabular}

表 3 : 検索語とファイル数

\begin{tabular}{|c|c|}
\hline 検臬铻 & $\begin{array}{l}\text { 模象牾每の } \\
\text { ファイル数 }\end{array}$ \\
\hline 建材 & 13417 \\
\hline 株 & 10689 \\
\hline メーカー & 6954 \\
\hline サンゲツ & 4366 \\
\hline 鋈料 & 3973 \\
\hline レンタルのニッケン & 3836 \\
\hline コンクリート & 3688 \\
\hline 建築 & 3098 \\
\hline トステム & 2992 \\
\hline ykk & 2790 \\
\hline
\end{tabular}

表 $2:$ 検索語とファイル種類

\begin{tabular}{|c|c|}
\hline & 湌索語毎のファ \\
\hline 梌來眖 & イル \\
\hline 株 & 3356 \\
\hline 建材 & 3248 \\
\hline メーカー & 1614 \\
\hline 建築 & 1282 \\
\hline 建築資材 & 1143 \\
\hline 建築材料 & 975 \\
\hline データベース & 940 \\
\hline 会社 & 823 \\
\hline 検索 & 760 \\
\hline 大阪 & 727 \\
\hline
\end{tabular}

表 $4:$ 検索語と平均ファイル数

\begin{tabular}{|c|c|}
\hline & 検穿䎸每の平均 \\
\hline 梌薁語 & ファイル数 \\
\hline エバラポンブ & 380.00 \\
\hline ジョインター & 332.50 \\
\hline キッチンハウス & 253.90 \\
\hline ヨコハマゴム & 231.00 \\
\hline キング通信工業 & 214.50 \\
\hline 日本鉏水 & 185.00 \\
\hline bacnet & 167.00 \\
\hline タカコム & 166.75 \\
\hline フッコー & 166.00 \\
\hline sherlock & 165.50 \\
\hline
\end{tabular}

(3)検索語毎の平均ファイル数

「検索語毎のファイル数ノファイル種類:検索語が取り出した 各ファイル数の平均値」

(2)を(1)で割ったもので、種類が少なく数が多いものが高い值 を示し、検索語の情報抽出能力を示す指標となる。

ファイル種類数、ファイル数それぞれの集計結果とも半数以上の 検索語が 1 種類、あるいは 1 個のファイルの抽出にのみ使われてい た。つまり、それぞれの集計結果の中央值が1であったので、ここ では、中央值以上の各パーセンタイルでの集計結果を記載している (表 $2 \sim 4$ )。

ここで、各々の集計結果の特徴を明らかにするため、得点の高い 検索語を比べると、ファイル種類（1) で得点の高いものは建材商 品のデータベースに関する一般的な語が多く（表 2)、ファイル数 （2）で見ると固有名詞が加わり（表 3）、平均ファイル数（3）で みると、具体的な商品名やメーカー名が多くなっていることがわか る(表 4) 注16)。

\section{5.利用者評価による分析}

\section{1 検索結果評価アンケート}

検索結果評価アンケートは、各ファイル毎にファイル内容が要求 するものであったかどうかを評価してもらうものである。各ファイ ルに評価のリンクを設け、その選択 (適／不適)を記録する仕組み を用意することで実現した（図 1)。

この記録には、評価、対象ファイル名、アンケート回答時刻、及 び refererに該当する項目が含まれている。

\section{2 評価の概要}

有効な評価が得られた件数（ログ数）は、99,132、その内、分類 検索の利用は 57,193、外部の情報検索サービスからの検索件数は 


\begin{tabular}{|c|c|}
\hline 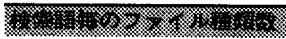 & 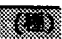 \\
\hline 90パーセンタイル & 3 \\
\hline 85パーセンタイル & 2 \\
\hline 75パーセンタイル & 2 \\
\hline 中央値 & 1 \\
\hline 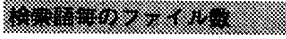 & $(x)$ \\
\hline 90パーセンタイル & 7 \\
\hline 85パーセンタイル & 4 \\
\hline 75パーセンタイル & 2 \\
\hline 中央値 & 1 \\
\hline Hex & (1) \\
\hline 90パーセンタイル & 2.5 \\
\hline 85パーセンタイル & 2 \\
\hline 75パーセンタイル & 1.3 \\
\hline 中央値 & 1 \\
\hline
\end{tabular}

37,011であった。外部の情報検索サービスからの検索に対する有効 な評価の件数は全体（4.2 参照）の約 4\%であった。

評洒対象となったファイル数は 7,383、外部の情報検索サービス からの検索に限ってみると6,003であった。全体 (4.2参照) と比較 すると約 $75 \%$ の数である。

外部の検索サービスからの検索結果について、4.3の(1)〜(3)の集 計を行った（表 5)。

全数での集計の場合 (4.3参照) と比較すると母数が少ないので、 検索語毎のファイル数は少なくなっているが、ファイルの種類はほ ほ同じあり、評価対象となったファイルは無作為抽出に近いと判断 できる。

検索語の特徴については、4.3とほほ同じ傾向を示していた。

\section{3 「分類検索」による検索の評価}

「分類検索」の場合は、アクセスパターンを評価するため、パター ン毎に集計し、適と評価された割合を評価値とした。ここで、アク セスパターンとは対象ファイルと、その直前に閲覧したファイルの 組み合わせのことであり、各アクセスパターンの対象ファイルの評
表 7 : ファイルのカテゴリ略称

\begin{tabular}{|c|c|}
\hline ファイルのカテコリ & 略称 \\
\hline 略称 & 㜔明 \\
\hline compdef & 企業情報一容トップベージ：50音順の索引 \\
\hline complist & 企業情報一監：社名の一覧変 \\
\hline compinfo & 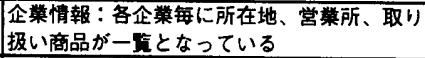 \\
\hline proddef & 分類検䨝トップベージ：大項目一監 \\
\hline proda & 分類検索：中項目一監 \\
\hline prodb & 分穎検枽：小項目、杜名一宜 \\
\hline prode & 分類検索：会杜所在地、商品情報一真 \\
\hline search & 外の情報檢索サービス \\
\hline & (以下は評価の対像外) \\
\hline dbnet & dbNETキーワード検索 \\
\hline dbnetimport & dbNET榆入盗材キーワード検索 \\
\hline other & その他 \\
\hline
\end{tabular}

価をそのアクセスパターンの評価とした。この結果を表 $6 に$ 示す。 表 6 中にあるファイルのカテゴリは表 7 の通りである。

この結果で特徴的な知見として次の 4 点が上げられる。

(1) 対象ファイルが商品情報の記述されているprodcであるパターン に評価が高い $(40 \%$ 以上) ものが多い。

(2) 特に compinfo から prodcを検索した場合の評価が高い。

(3) prodc から compinfo のパターンも評価が高い。

(4) 対象ファイルが proda 〜 b、 complist など項目や社名の一覧ファ イルは評価が低い。

\section{4 「外部の情報検索サービス」による検索の評価}

「外部の情報検索サービス」の場合は、キーワードの評価を行う ため、キーワード毎に評価値を算出した（表 8)。算出方法は、次の 順序に従う。

1. 対象ファイル毎に評価を集計し、適の回答の割合を求める。

2. 对象ファイル毎に抽出された検索語の、元の対象ファイルに対す る適率を1.の割合とする。

表 8 :「外部の情報検索サービス」による検索の評価（一部）

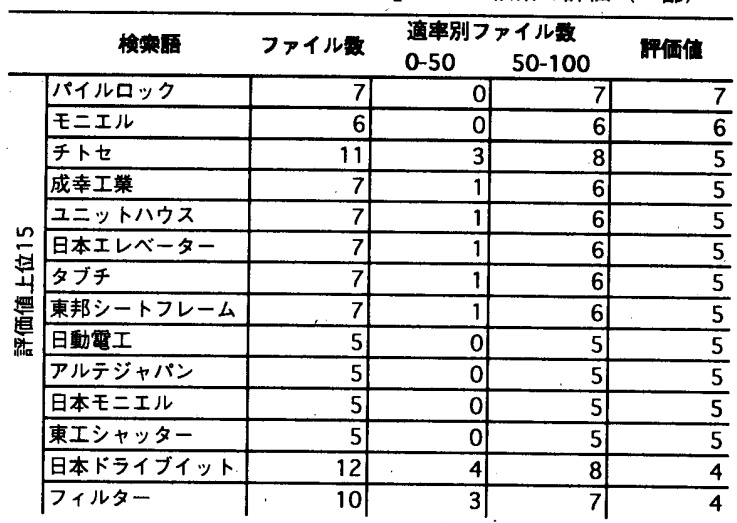

\begin{tabular}{|c|c|c|c|c|}
\hline データベース & 28 & 26 & 2 & -24 \\
\hline 建設資材 & 33 & 29 & 4 & -25 \\
\hline 材料 & 35 & 31 & 4 & -27 \\
\hline or & 48 & 38 & 10 & -28 \\
\hline 検霜 & 34 & 32 & 2 & -30 \\
\hline ガラス & 37 & 34 & 3 & -31 \\
\hline アルミ & 46 & 41 & 5 & -36 \\
\hline コンクリート & 95 & 67. & 28 & -39 \\
\hline 邆料 & 85 & 65 & 20 & -45 \\
\hline 建案材料 & 66 & 59 & 7 & -52 \\
\hline 建築 & 87 & 72 & 15 & -57 \\
\hline 建案筫材 & 81 & 73 & 8 & -65 \\
\hline$x-n-$ & 168 & 139 & 29 & -110 \\
\hline 株 & 498 & 348 & 150 & -198 \\
\hline
\end{tabular}


3. 検索語毎に適率を集計し、評価が良い（適率 50\%以上）ものか ら評価が悪い (適率 50\%未渵) ものを引いた数を評価值とする。

例えば、表 8 の3行目のデータ（検索語「チトセ」）では、適率 50\% 未満（0-50）が3、適率 50\% 以上（50-100）が8、評価值は 5（=8 -3) となる。

ここで、適率とはある検索語を利用したときに検索の結果が適当 である確率ととらえられる。

評価值上位と下位のもので固有名詞の出現率を比較しところ、上 位（評価值 3 以上）における出現率は $79 \%(68 / 86)$ 、下位（-10以下） における出現率は $18 \%$ （20/111）であった。本データベースにおい て各ファイルには企業名や商品名が記載されており、これら固有名 詞を検索語とした検索は的確な検索が行える可能性が高いと仮定す ると、この評価值によりある程度適切に検索語が評価されていると いえる。

\section{6. 考察}

\section{1 利用者評価の有効性}

4.3 から単純に考えると、平均ファイル数の多い検索語の評価が 高くなるが、利用者による評価結果（5.4）を見ると、平均ファイル 数と評価値とは相関が低い。このことから、単純な統計的手法では 適切に検索語の評価を行うことができないことが明かとなった。つ まり、適切な検索語の評価にあたっては、今回導入した利用者によ る評価手法が必要であることがわかる。

\section{2 検索方法の比較}

「分類検索」と「外部の情報検索サービスからの検索」の評価値 を比較すると、5.3（表 6）より、前者は 40\%（適：23,006、不適： 34,187 )、後者は $34 \%$ (適: 12,469 、不適 $: 24,375$ ) であり、前者が 2 割ほど評価值が高いことがわかる。

この比較は、カテゴリー（ディレクトリ）検索と、キーワード検 索の比較ともいえる。つまり、建材データベースを対象とした今回 の分析の範囲では、カテゴリー検索の方が優れていると考えられ る。

\section{3 対象データベースの検証}

建材を対象とした場合は、商品情報（prodc）から、より詳細な情 報がある企業情報（compinfo）を検索することが多いと想定して データベースを作成していたが、このパターンの評価（5.3の評価 （3）よりも企業情報から商品情報を検索する逆のパターンの評価 (同(2)）が高いことが明らかとなった。このことは通常の建材デー タベースに見られない情報収集行動があることを示唆している。

5.3 の評価(4)より、分類項目の小項目、社名一覧 (prodb) の評価 が低かった。ここには取り扱い製品の詳細な種別と、社名、連絡先 が記述してあり情報量として適当であると判断していたが、これら の情報が必ずしも一覧できることにメリットは少なく、データベー ス構造に改良の余地があることが明らかとなった。

「分類検索」による結果から、データベース内のキーワード検索 (dbnet)においても、商品情報（prodc）以外は必要とされていない と考えられる。このことから、商品情報を優先的に提示するよう検 索結果に重み付けを行う必要があることが明らかとなった。

さらに、同じキーワード型検索システムでも、輸入建材検索 (dbnetimport)の評価が低いことが明らかとなった。このことは、利
用者評価を導入した今回の手法により、通常のログ解析だけからは 分からないデータベースの評価も行えたことを示している。

\section{4 まとめ}

以上のように、ネットワーク上で公開されたデータベースにおい て、実装の容易な方法でエキスパートジャッジメントを取り入れた 利用者評価が行えることを示すことができた。

今回のケーススタディーでは、データベース設計者の意図してい ない隠れた情報収集行動や、データベースの改良点も明らかにする ことができた。

今後は、検索効率の向上のために、本評価手法を自動化して実働 システムへ組み込み、さらに検証を重ねることが課題となる。

注

注 1）従来、ディレクトリ型、全文検索型などに分類されていたが、最近で は複合的な検索サービスを提供したり、情報のリンク関係を分析して 検索結果に重み付けをするものも登場している。

注 2）一般的な検索サービスに関する研究は多いが、専門的な検索サービス が求められている。

注 3）建材を対象とした検索用語のシソーラス策定のため建設業、建材メー カーのエキスパートを集めて作業を行ったことがあるが、極めて限定 された分野においても萗葉の定義が一定でないなど、従来の方法によ るシソーラス策定の難しさを実感した。

注. 4) http://www.dbnet.gr.jp/

注 5) 以降、断りのないかぎりファイル数、アクセス数は対象期間内（2000 年1月1日～12月31日）における集計結果である。

注 6）商品情報、メーカー情報の記載されたファイルを主要ファイルと呼 ぶ。それ以外のファイルは、分類検索におけるインデックスファイル などである。

注 7) 有効回答数1035。利用者属性内訳は次のとおりである。工事業者 $33 \%$ 、 設計者 $29 \%$ 、メーカー $10 \%$ 、販売流通 $8 \%$ 。その他 $20 \%$ 。

注 8）本データベースの場合検索結果に商品の分類、メーカーの連絡先など 主要な情報が含まれるため、的確な判断が可能である。

注 9）実際には図に示した 4 項目以外に 10 項目程度ずつ記録されており、一 月分のログファイルは $400 \mathrm{MB}$ 程度になる。令回解析した 2000 年一年 間では 4.7GB の容量になっている。

泣 10) 利用者が直前に参照していたページを知る仕組み。ほとんどのフラウ ザーとサーバーがこの機能に対応している。英単語としては、referrer が正しいつづりだが、テクニカルタームとしてはこのつづりが用いら れている。

注 11) 利用者からの検索指令はCGIというプロトコルで情報検索サービスを 提供するサーバーに送信されるが、その送信方法にはGETとPOSTの 二つがある。GETでは送信内容が URL 形式で記述され、本稿に示す ように第三者のサーバーにもその内容が明らかとなる。 GETではこのように情報のやりとりが簡単に見られてしまうことや、 送信容量に制限があるなど制約があるが、初期から採用されているた めかよく利用されているようである。

注 12）本研究では利用できなかったが、これらの情報を元にログを解析する プログラムもいくつかあり、単純に検索に使わ机た検索語を抽出する ものもある。

注 13）付加情報は「?」記号に続けて記載するとURLの规約で規定されてい るので、この記号を含む行を抽出する。

注 14) URL (RFC 1738:ftp://ftp.iij.ad.jp/pub/internet/ffc/rfc 1738.txt) やHTML (RFC 1866：ftp://ftp.iij.ad.jp/pub/internet/ffc/rfc1866.txt)の定義に従っ てデコードしている。

注 15）異なるサービスで同じ指令を用いていたり、システムを変更するサー ビスなどもあるので、解析のたびに一連の作業が必要となる。しかし、 最近は新しい検索サービスの登場が減っているため状況は改善されそ うである。

注 16）本文中の表では例としてそれぞれ得点上位 10 個の検索語を載せた。 


\section{参考文献}

1）林 良彦他: WWW I.の検索サービスの技術動向、情報処理、Vol.39 No.9、pp.861-865、情報処理学会、1998

2）佐藤 進也他: WWW トラフィック解析による情報生産者と情報消費者 の数量的特幑づけ、情報処理学会誌、Vol.40 No.7、pp.2851-2860、情報 処理学会、1999

3）大久保 雅且他: WWW 検索ログに基づく情報ニーズの抽出、情報処理 学会誌、Vol.39 No.7、pp.2250-2258、情報処理学会、1998

4) Srinivassan, P.: Thesaurus Construction, Information Retrieval: Data Structures \& Algorithms, Frakes, W.B. and Beza-Yates, R. (Eds.), pp.161-218, Prentice Hall, NJ (1992)

本文献では、二つの単語W 1 と $\mathbf{w} 2$ の結合度（関連性）を関連するファイ ル数をもとに次式で定義している。
5）岩崎 正秀他: 可変なカテゴリ構造を用いた文書検索支援手法の実験的 評価, 情報処理学会研究報告, DBS120, pp.1-8, 情報処理学会、2000

6）木村 謙他：WWW上での建築情報データベースの構筑、20回情報シス テム利用技術シンポジウム梗概集、日本建築学会、1997

7) 日本建築学会編: 建築学用語辞典第 2 版、岩波書店、1999

8）建築用語編集委員会編: 建築用語辞典第 2 版、技報堂出版、1999

9）竹本 義美他:辞書およびパターンマッチルールの增強と品質強化に基 づく日本語固有表現抽出、情報処理学会誌、Vol.42 No.6, pp. 1580-1591、 情報処理学会、2001

（2002年10月 9 日原稿受理, 2003 年 4 月 23 日採用決定） 